\title{
PEMANFAATAN TEKNOLOGI PENGELOLAAN OPT TANAMAN SAYURAN BERBAHAN BAKU RAMAH LINGKUNGAN DI KANAGARIAN LASI KECAMATAN CANDUANG KABUPATEN AGAM
}

\author{
Ujang Khairul "), Arneti dan Reflin \\ Universitas Andalas \\ ${ }^{*}$ Email : jgkhairul@gmail.com
}

\begin{abstract}
ABSTRAK
Kegiatan tentang pemanfaatan teknologi pengelolaan organisme penganggu tanaman (OPT) pada tanaman sayuran berbahan baku ramah lingkungan telah dilakukan di Kelompok Tani Mitra di Nagari Lasi Kecamatan Canduang Kabupaten Agam pada bulan September hingga November 2016. Kegiatan ini bertujuan untuk meningkatkan pengetahuan petani tentang serangan OPT sayuran dan bagaimana mengelola OPT menggunakan biopestisida dan pestisida botani. Kegiatan ini meliputi: pemantauan tingkat serangan OPT di lahan mitra, penyuluhan, pelatihan, dan evaluasi hasil kegiatan. Hasil pemantauan tingkat serangan OPT pada tanaman sayuran mitra berkisar antara $18-27 \%$ untuk penyakit dan $15-20 \%$ untuk hama. Dari kegiatan dapat dikesimpulkaan yaitu: (1) tingkat OPT pada tanaman sayuran mitra cukup tinggi, (2) Petani belum memahami OPT yang menyerang tanaman sayuran mereka, (3) Petani tidak memahami metode pengelolaan OPT menggunakan biopestisida dan pestisida botani, dan (4) penyuluhan dan praktek lapangan, telah meningkatkan pengetahuan petani tentang pengelolaan OPT sayuran dengan menggunakan biopestisida dan pestisida botani.
\end{abstract}

Kata Kunci : tanaman sayuran, biopestisida, pestisida nabati, Nagari Lasi

\section{Utilization of Vegetables Based on Environmental Friendly Plant Optimization Technology in Kanagarian Lasi Kecamatan Canduang Agam District}

\begin{abstract}
Activity of use management technology for pest and plant disease control on vegetables based environment friendly in Nagari Lasi, Kecamatan Canduang, Kabupaten Agam has been carried out from September to November 2016. This activity aims to improve farmers knowledge about the pest and plant disease attack of vegetables and know how to manage the pest and plant disease using biopesticide and botanic pesticide. These activities include: Monitoring of pest and plant disease, counseling, training, and evaluation. Results of monitoring the pest and plant disease in vegetable crops rate ranged between 18 $27 \%$ for disease and $15-20 \%$ for pest. From the activities can be take conclusions: (1) level of pest and plant disease in vegetable crops in this area is high, (2) The farmers do not yet understand the causes of pest and plant disease that attack their vegetable crops, (3) The farmers do not understand the methods of pest and plant disease control using biopesticide and botanic pesticide, (4) The extension and field practice, have improved farmers' knowledge about the management of vegetable diseases using biopesticides and botanic pesticide
\end{abstract}

Keyword : Vegetatable crops, biopesticide, botanic pesticide, Nagari Lasi

\section{PENDAHULUAN}

Kabupaten Agam merupakan salah satu kabupaten di Sumatera Barat dengan luas wilayah 2.232,30 km², Kabupaten ini termasuk sebagai salah satu Kabupaten agraris yang struktur ekonomi masyarakatnya didominasi oleh sektor pertanian dengan sub sektor tanaman pangan, hortikultura dan tanaman perkebunan. Peran sektor pertanian 
dalam pembentukan PDRB adalah sebesar 39,72\% dan laju pertumbuhan sektor ini mencapai $7.01 \% / t a h u n$, sementara itu sub sektor tanaman hortikultura menyumbang 21,11\% terhadap PDRB kabupaten Agam (Badan Pusat Statistik, Kabupaten Agam, 2014). Luas area yang tersedia untuk pengembangan komoditas hortikultura di Kabupaten Agam mencapai 22 275,75 Ha (Bappeda Kabupaten Agam, 2015)

Kecamatan Canduang merupakan salah satu Kecamatan di Kabupaten Agam yang menjadi daerah sentra produksi tanaman hortikultura (sayuran). Kecamatan ini terletak +/- $1150 \mathrm{~m}$ dpl. Luas areal sayuran di kecamatan ini mencapai 394 Ha dengan produksi beberapa tanaman sayuran seperti Cabe ( 837 ton/tahun), kubis (3640 ton/tahun), tomat (867 ton/tahun), dan bawang daun (837 ton/tahun) (Canduang Media Center, 2015). Peningkatan pertumbuhan luas lahan sayuran dari tahun 2010 - 2014 mencapai 0,93\%. Sekitar 20 - 40\% dari produk sayuran ini setiap hari dikirim ke daerah tetangga seperti Riau, Jambi dan Bengkulu dan juga di ekspor ke Malaysia (Bappeda Kabupaten Agam, 2015). Beberapa tanaman sayuran andalan yang dihasilkan daerah ini adalah kubis, cabai merah, tomat, kentang, dan brokoli. Kelompok tanaman ini mempunyai nilai ekonomis yang tinggi dan banyak digunakan sebagai lalapan dan bumbu dalam masakan sehari-hari rumah tangga di Indonesia. Menurut Setiadi (2002), sayuran ini mengandung kalori, protein, karbohidrat, vitamin dan mineral yang cukup tinggi.

Tanaman sayuran memiliki potensi pengembangan sangat baik, permintaan pasar akan komoditi tanaman sayuran cenderung meningkat berkaitan dengan pertumbuhan jumlah penduduk, industri pariwisata yang makin berkembang. Faktor pendukung yang strategis bagi pengembangan agribisnis sayuran Kecamatan Canduang adalah tersedianya sumberdaya alam dan sumberdaya manusia yang memadai serta faktor letak yang dekat dengan kota-kota besar di Sumatera. Sebahagian besar petani di Kecamatan ini menanam tanaman sayuran secara monokultur atau secara tumpang sari dengan tanaman lain, seperti seledri, dan bawang daun. Dalam mengusahakan tanamannya, petani selalu dihadapkan dengan beberapa masalah yang membatasi usaha peningkatan produksi, salah satunya adalah serangan hama dan penyakit, beberapa penyakit penting yang sering menyerang tanaman sayuran di daerah ini adalah layu bakteri (Ralstonia solanacearum (E.F. Smith), layu fusarium (Fusarium oxysporum), penyakit antraknosa (Colletotrichum capsici) dan penyakit busuk basah dan busuk lunak (Erwinia coratovora), sedangkan hama penting yang sering ditemukan adalah : Lalat penggorok daun (Liriomyza huidobrensis), ulat gerayak (Spodoptera litura) ulat kubis (Plutella xylostella) (Dinas Pertanian Tanaman Pangan, Hortikultura dan Peternakan Kabupaten Agam, 2014). Hama dan penyakit ini dapat menyebabkan kehilangan hasil yang cukup tinggi, pada serangan berat akibat serangan hama dan hama dan penyakit ini dapat menyebabkan kehilangan hasil sampai 100\% (Semangun, 2000).

Untuk mengendalikan hama dan penyakit tersebut, petani sayuran di daerah ini rutin menggunakan pestisida sintetis seperti insektisida, fungisida dan bakterisida. Biaya yang dikeluarkan untuk pembelian pestisida mencapai 20\% dari biaya produksi (Dinas Pertanian Tanaman Pangan, Hortikultura dan Peternakan Kabupaten Agam, 2014). Rata-rata petani sayuran menyemprot tanamannya 18 kali dalam satu musim atau dengan interval 3- 5 hari, tidak sedikit petani yang menyemprot lebih pendek dari pada interval tersebut, terutama apabila turun hujan. Dalam sekali semprot petani menggunakan bermacam merek pestisida yang target jasad penganggunya hampir sama, dan petani sayuran ini terlihat kurang memperhitungkan sisi kesehatan sewaktu menyemprot pestisida. Petani sayuran di daerah ini merasa puas apabila tanaman 
sayuran mereka telah disemprot dengan pestisida sintetis.

Praktek penggunaan pestisida sintesis yang intensif dan tidak bijaksana dan tanpa mempertimbangkan keseimbangan ekologis dan ekonomi akan memunculkan banyak efek yang merugikan diantaranya: tingginya biaya produksi, timbulnya resistensi, resurjensi dari Organisme Pengganggu Tumbuhan (OPT). Disamping itu sekarang terjadi kecenderungan konsumen sayuran yang lebih memilih produk sayuran yang bebas residu pestisida terutama di negara tujuan ekspor sayuran seperti Singapura dan Malaysia. Apabila hal ini tidak diperhatikan maka produk sayuran yang diekspor akan ditolak oleh konsumen luar negeri.

Sesuai dengan program pertanian berkelanjutan yang diterapkan di Indonesia maka teknik pengendalian Organisme Pengganggu Tumbuhan (OPT) pada tanaman sayuran harus mengacu pada Pengendalian Hama dan Penyakit secara Terpadu (PHT). Salah satu komponen utama dari program PHT adalah pengendalian hayati dengan memanfaatkan agensia pengendalian hayati (biopestisida dan pestisida botani). Keuntungan penggunaan biopestisida dan pestisida botani antara lain: ramah lingkungan, berkesinambungan, kesesuaian ekologis, dan dapat diintegrasikan dalam program PHT serta dapat diperbanyak dengan teknologi yang sederhana dan mudah cara aplikasinya.

Bertitik tolak dari semua permasalahan di atas dan dari hasil penelitian sebelum yang dilakukan oleh tim pelaksana kegiatan telah didapatkan beberapa biopestisida dan pestisida botani yang telah diformulasi dengan menggunakan bahan amendeman berupa limbah air kelapa, molase dan ampas tebu. Biopestisida dan pestisida botani ini dapat digunakan sebagai penganti pestisida sintetis untuk pengelolaan beberapa hama dan penyakit penting yang sering menyerang tanaman sayuran petani di daerah ini. Kegiatan ini dimaksudkan guna pengentasan kemiskinan melalui kemandirian petani dalam menyediakan sarana produksi, meningkatkan ketersedian produk sayuran melalui kegairahan dan kesungguhan dalam budidaya tanaman hortikultura umumnya dan sayuran khususnya, peningkatan nilai jual produk sayuran dengan komoditi ramah lingkungan dan aman dikonsumsi.

Pada bulan Maret dan September 2015 tim pengusul telah melakukan penjajakan kepada kelompok tani sayuran ini, Penjajakan dilakukan untuk melihat kondisi dan potensi lokal yang disekitar kelompok tani ini dan sinergisnya dengan kebijakan pemerintah daerah. Penjajakan ditujukan untuk mendapatkan sebanyak mungkin data awal yang akan digunakan untuk mengidentifikasi masalah dan mengevaluasi potensi lokal yang bisa dimanfaatkan untuk pemecahan masalah terutama dalam memanfaatkan produk biopestisida berbasis limbah pertanian, pestisida botani, dan pupuk organik berbahan baku tanaman lokal. Setelah didiskusikan dengan petani mitra beberapa masalah yang berhasil diidentifikasi adalah sebagai berikut:

1. Adanya serangan OPT yang menyerang tanaman sayuran mitra, diantaranya : hama Lalat penggorok daun (Liriomyza huidobrensis), ulat gerayak (Spodoptera litura), ulat kubis (Plutella xylostella) dan penyakit layu (bakteri dan jamur), antraknosa, dan busuk basah dan busuk lunak, menurut petani mitra kalau tidak dikendalikan dari awal akan menyebabkan kehilangan hasil sampai sampai $100 \%$.

2. Mitra masih menggunakan pestisida sintetis sebagai alternatif utama untuk mengendalikan OPT yang menyerang tanaman sayuran mereka. Akibat penggunaan pestisida sintesis yang sangat intensif, selain akan menyebab naiknya biaya produksi juga dikhawatirkan akan menyebabkan terjadinya resistensi dan 
resurgensi pada Organisme Penganggu Tanaman (OPT), terjadinya keracunan pada manusia dan hewan lain serta menimbulkan dampak yang tidak baik terhadap lingkungan, seperti adanya pencemaran lingkungan, matinya musuhmusuh alami yang bermanfaat.

3. Untuk mengatasi persoalan pada mitra perlu dicarikan alternatif pengendalian yang mampu menekan biaya produksi dan sekaligus relatif aman terhadap lingkungan yaitu dengan menggunakan biopestisida. Penggunaan biopestisida nabati ini dapat mengurangi residu beracun pada produk sayuran sehingga aman untuk dikonsumsi. Mikroba yang digunakan sebagai bahan aktif biopestisida tersebut adalah bakteri yang bersifat antagonis diantaranya adalah bakteri Pseudomonas fluorescens, (Habazar et al, 2000: Yanti et al, 2008), Bacillus subtilis (Khairul dan Winarto, 2005) dan Streptomyces sp. (Khairul dan Reflin, 2008), sedang untuk pestisida botani dapat menggunakan ekstrak dari daun gambir, ekstrak Thitonia sp dan daun ruku-ruku (Arneti, 2004).

4. Pemanfaatan biopestisida dan pestisida nabati untuk pengendalian hama dan penyakit pada tanaman sayuran dapat dilakukan, karena bahan aktifnya sudah ada di alam, namun belum dimanfaatkan secara maksimal oleh petani, disamping itu pembuatan formulasi dan aplikasinya di lapangan tergolong mudah. Untuk meningkatkan efisiensi dan mempertahankan keberadaannya dalam waktu yang panjang pada kondisi optimal, biopestisida dan pestisida nabati dapat diintroduksikan dalam berbagai bentuk formula.

Melalui pelaksanaan kegiatan ini ditargetkan :

1. Petani mitra memiliki pengetahuan dan ketrampilan yang cukup dalam pembuatan biopestisida, pestisida botani yang dapat digunakan untuk mengendalikan OPT pada tanaman sayuran mereka.

2. Terjadi penurunan penggunaan pestisida sintetik dan peningkatan penggunaan biopestisida, pestisida botani yang dapat digunakan untuk mengendalikan OPT pada tanaman sayuran mereka.

3. Terjadi perubahan perilaku dari pelaksanaan sistim pengendalian OPT pada tanaman sayuran ke arah penggunaan biopestisida, pestisida botani sehingga kelestarian lingkungan lebih terjaga dan biaya produksi bisa ditekan.

4. Petani mitra bersatu membentuk sebuah kelompok tani yang solid dan berpengetahuan cukup untuk melanjutkan pembuatan biopestisida, pestisida botani

Luaran dari kegiatan ini adalah petani-petani mandiri yang mempunyai pengetahuan, wawasan, informasi, teknologi bagi petani sehingga dapat mengurangi ketergantungan petani terhadap pestisida sintetis. Secara ekonomis kegiatan ini juga akan memberikan keuntungan bagi petani nantinya dalam hal peningkatan pendapatan karena biaya yang digunakan untuk pembelian pestisida sintetis dapat ditekan, dengan demikian diharapkan terbangunnya kemandirian dalam produksi usaha tani dan sekaligus meningkatkan pendapatan keluarga petani mitra. 


\section{METODE}

Khalayak sasaran dalam kegiatan ini adalah kelompok tani sayuran yang ada di Kanagarian Lasi yaitu Kelompok Tani "Koto tangah Azhari" Kecamatan Canduang Kabupaten Agam. Jumlah anggota kelompok tani adalah sebanyak 20 orang dengan harapan nantinya anggota kelompok tani tersebut dapat menyebarluaskan informasi dan pengetahuan yang diperoleh kepada petani lainnya melalui efek tetesan minyak.

Metode yang digunakan dalam kegiatan ini adalah sebagai berikut:

\section{Survey Pendahuluan Serangan OPT Dilapangan dan Pendekatan Sosial}

Tahap ini bertujuan untuk mengetahui tingkat serangan OPT pada lahan sayuran mitra dan melakukan komunikasi dan sosialisasi maksud dan tujuan kegiatan disampaikan melalui ketua kelompok tani mitra. Dari kegiatan ini diharapkan terciptanya suatu kerjasama antara masyarakat, unit pengelola penyuluhan berbasis petani dan aparat pemerintah. Selain itu, kegiatan ini akan memperoleh legitimasi bagi semua kegiatan yang berkaitan dengan pelaksanaan kegiatan, sehingga dukungan semua pihak dapat diperoleh. Masyarakat bersedia untuk mengikuti kegiatan ini serta menyediakan waktu.

\section{Sosialisasi dan Penyuluhan}

Tim pelaksana kegiatan dengan anggota kelompok petani berkumpul di ruang pertemuan kelompok tani Koto Tangah Azhari Nagari Lasi Kecamatan Canduang, Kabupaten Agam. Kegiatan ini bertujuan untuk memberikan materi penyuluhan berupa:

a. OPT yang sering menyerang tanaman sayuran dampak negatif penggunaan pestisida sintetik yang intensif dan tidak bijaksana dalam pengendalian OPT.

b. Pemanfatan biopestisida, pestisida botani dalam pengendalian OPT tanaman sayuran.

c. Pengenalan cara pembuatan, perbanyakan dan penggunaan biopestisida, pestisida botani.

\section{Praktek}

Praktek yang dilaksanakan bertujuan untuk menambah wawasan dan pengetahuan petani tentang pembuatan biopestisida, pestisida botani yang bahan bakunya ada di alam. Praktek dilakukan pada semua anggota kelompok tani mitra. Kegiatan penyuluhan, diskusi dan praktek dilakukan 1 hari penuh.

\section{Rancangan Evaluasi}

Melakukan evaluasi berupa pre-test yang dilakukan sebelum kegiatan dan post-test setelah pelaksanaan kegiatan. 


\section{HASIL DAN PEMBAHASAN}

\section{Pemantauan Serangan OPT Dilahan Sayuran Mitra}

Hasil pemantauan terhadap tingkat serangan OPT pada tanaman sayuran yang dilakukan sebelum kegiatan penyuluhan memperlihatkan bahwa sebahagian besar tanaman sayuran yang diusahakan oleh kelompok tani ini seperti; kubis, cabai, dan bawang daun terserang oleh OPT seperti: penyakit busuk basah, dan akar gada (kubis), penyakit antraknosa, layu bakteri dan bercak daun (cabai), busuk umbi (wortel) dan hawar daun bakteri (bawang merah) terlihat pada Gambar 1.

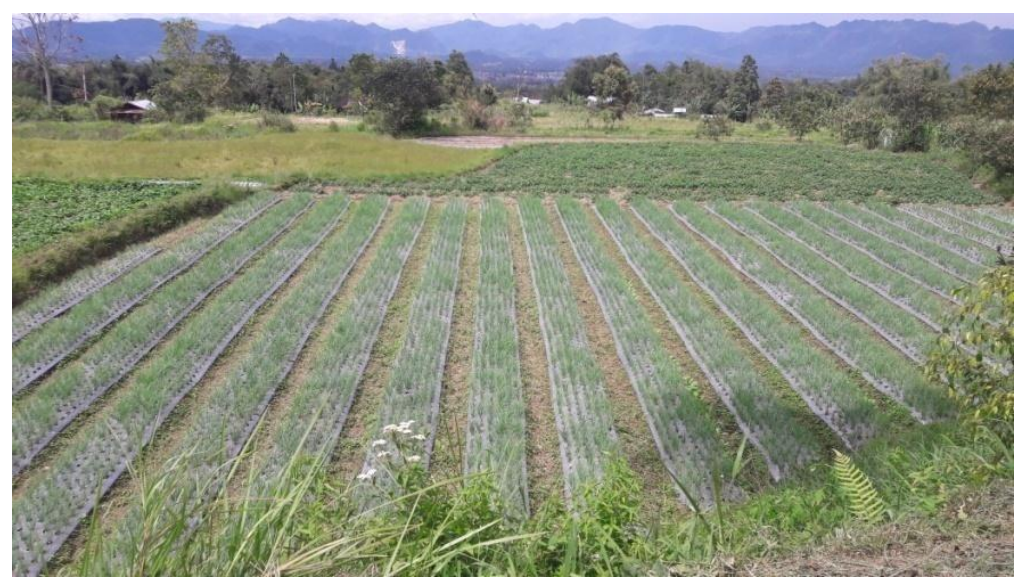

Gambar 1. Kebun Bawang Merah Kelompok Tani Mitra

Tingkat serangan hama pada tanaman sayuran di kelompok tani ini berkisar antara 15-20\%, sedangkan serangan patogen penyebab penyakit antara 18-27\%. (Tabel 1 dan Gambar 2). Hama yang ditemukan adalah : Lalat penggorok daun (Liriomyza huidobrensis), ulat gerayak (Spodoptera litura) ulat kubis (Plutella xylostella), kutu daun (Myzus persicae) dan Lalat buah (Trips sp) (Gambar 3).
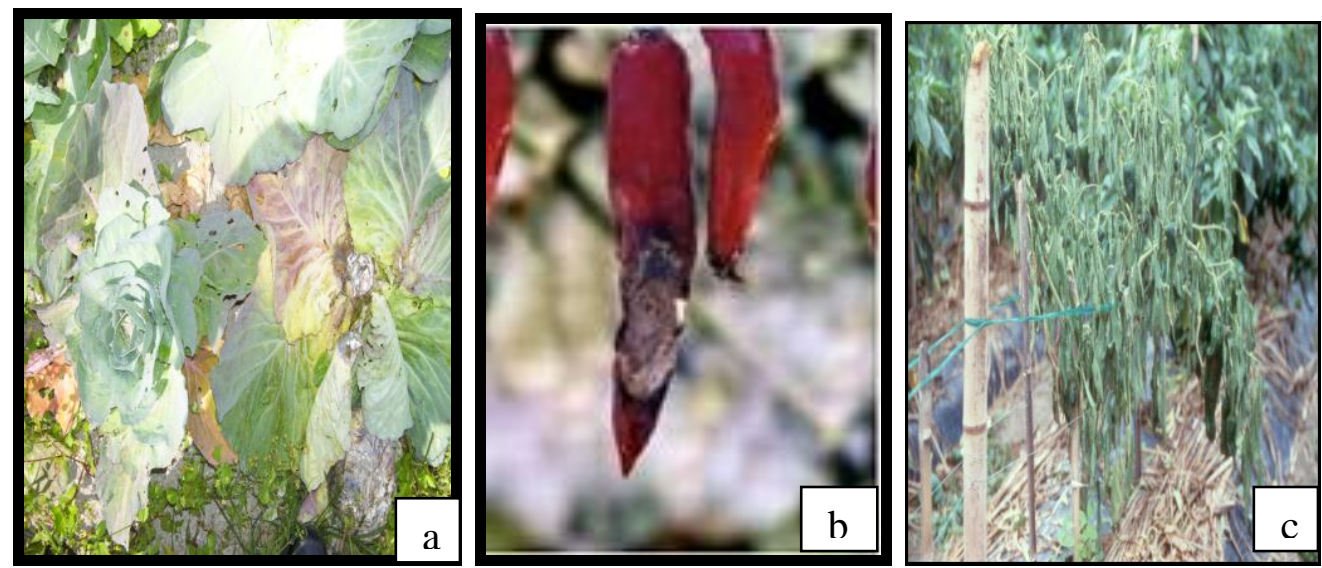

Gambar 2. Beberapa Penyakit Yang Menyerang Tanaman Sayuran Petani Dilapangan. (a) Busuk Lunak Pada Kubis, (b) Antraknosa Pada Cabai dan (c) Layu Bakteri Pada Cabai. 

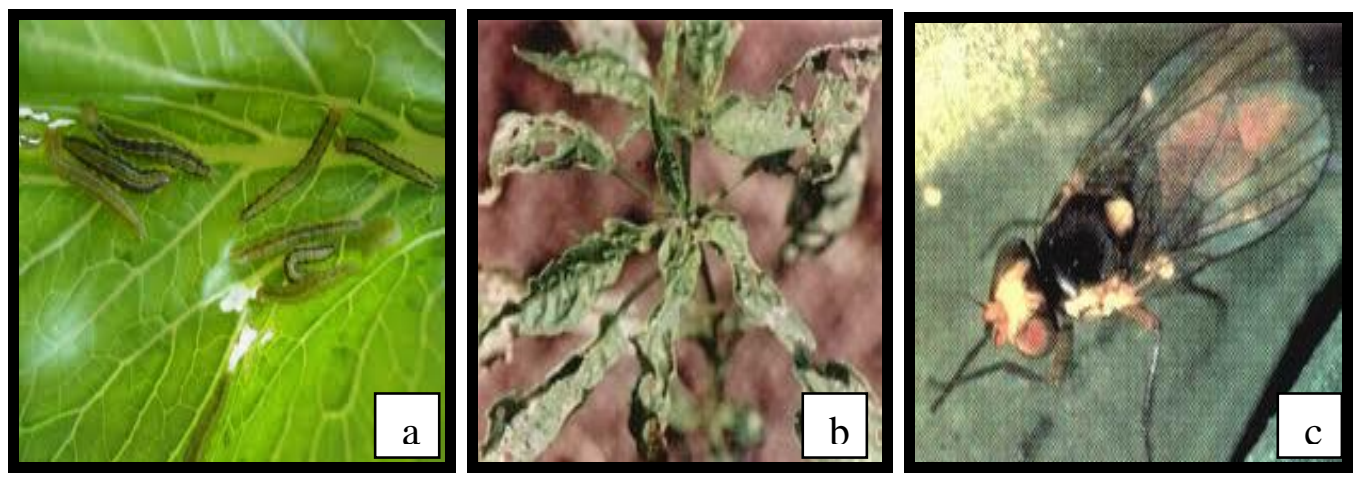

Gambar 3. Beberapa Hama Yang Menyerang Tanaman Sayuran Petani Dilapangan (a), Plutella xylostella, (b) Kutu Daun dan (c) Lalat Buah.

Untuk mengatasi OPT ini, anggota kelompok tani selalu mengandalkan penggunaan pestisida sintetis (bakterisida, fungisida dan insektisida) yang intensitas penyemprotan cukup tinggi yakni setiap 3 hari, apabila sering hujan menjadi setiap $1-2$ hari.

Tabel 1. Jenis OPT yang menyerang tanaman sayuran di lahan kelompok tani Koto Tangah Azhari

\begin{tabular}{|l|l|l|l|}
\hline No & \multicolumn{1}{|c|}{ Jenis Sayuran } & \multicolumn{1}{c|}{ Hama*) } & \multicolumn{1}{c|}{ Penyakit*) } \\
\hline 1 & Kubis & $\begin{array}{l}\text { 1. Crocidolomia binotalis } \\
\text { 2. Plutella xylostella }\end{array}$ & $\begin{array}{l}\text { 1. Busuk basah } \\
\text { 2. Akar gada }\end{array}$ \\
\hline 2 & Bawang daun & $\begin{array}{l}\text { 1. Ulat gerayak } \\
\text { Spodoptera exigua }\end{array}$ & $\begin{array}{l}\text { 1. Bercak daun bakteri } \\
\text { 2. Bercak daun altenaria }\end{array}$ \\
\hline 3 & Cabai & $\begin{array}{l}\text { 1. Kutu daun (Myzus } \\
\text { persicae) }\end{array}$ & $\begin{array}{l}\text { 1. Antraknosa (C.capsisi) } \\
\text { 2. Layu bakteri }(\text { R. } \\
\text { Solanacarum) }\end{array}$ \\
& & $\begin{array}{l}\text { 2. Ulat gerayak } \\
\text { (Spodoptera litura) }\end{array}$ & $\begin{array}{l}\text { 3. Bercak daun } \\
\text { (X.a.pv.visicatoria) }\end{array}$ \\
& & 2. Lalat buah (Trips sp) & \\
\hline & & & \\
\hline
\end{tabular}

*) dokumentasi hama dan patogen penyebab penyakit terlampir

\section{Pengenalan dan Diskusi Tentang OPT Utama Yang Menyerang Tanaman Sayuran}

Sebahagian besar anggota kelompok tani belum mengenal OPT yang menyerang sayuran yang mereka usahakan. Dari hasil pre-test yang dilakukan sebelum kegiatan pengenalan hama dan penyakit yang menyerang sayuran, $87 \%$ peserta tidak mengetahui jenis OPT yang menyerang sayuran. Anggota kelompok tani ini belum bisa membedakan tanaman yang terserang bakteri, jamur atau virus. Setelah dikenalkan dengan gejala-gejala serangan hama dan penyakit, anggota kelompok tani mulai dapat membedakan jenis-jenis OPT yang menyerang sayuran mereka. (Gambar 4) 


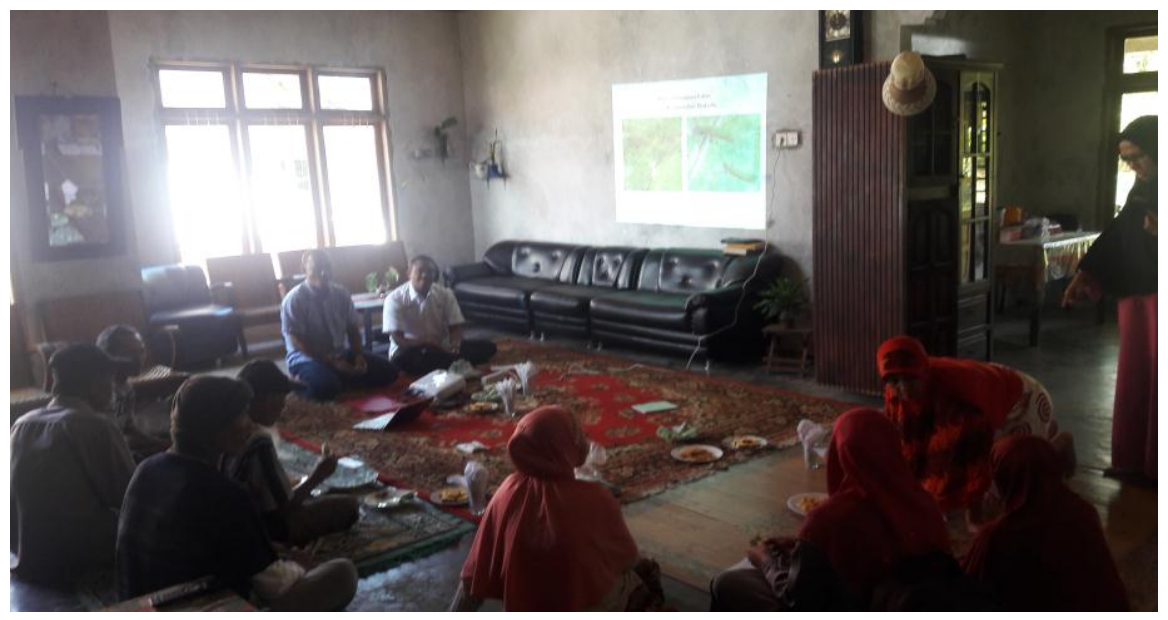

Gambar 4. Peserta Kegiatan Mendengarkan Materi Yang Disampaikan Oleh Tim

Dari hasil diskusi dengan anggota kelompok tani diketahui bahwa anggota kelompok tani menggunakan pestisida sintetik untuk mengendalikan OPT pada sayuran, sebahagian besar pestisida-pestisida yang digunakan belum tepat jenis dan sasarannya. Kadang-kadang pestisida sintetik ini dicampurkan satu sama lainnya, padahal ada pestisida yang bahan aktifnya sama sehingga dari sisi analisa usaha tani, hal seperti ini akan meningkatkan biaya tani (modal).

\section{Praktek Pembuatan Pestisida Hayati (Biopestisida), Pestisida Nabati}

Pada kegiatan ini anggota kelompok tani dilatih untuk membuat pestisida hayati, pestisida botani berbahan baku lokal. Untuk pembuatan pestisida hayati digunakan Trichoderma harzianum, Pseudomonas flourescens dan Bacillus sp. T. harzianum diperbanyak dengan menggunakan dengan sekam, jerami padi, dan ampas tebu steril Pseudomonas flourescens dan Bacillus sp. Diperbanyak dengan menggunakan air kelapa dan tepung tapioka steril. Pestisida nabati dibuat dengan menggunakan bahan baku lokal seperti: akar tuba,daun dan bunga kipait, daun sirsak. Bahan-bahan ini ditumbuh/digiling dan diperas, air perasan digunakan untuk pengendalian OPT (Gambar 5,6 , dan 7).

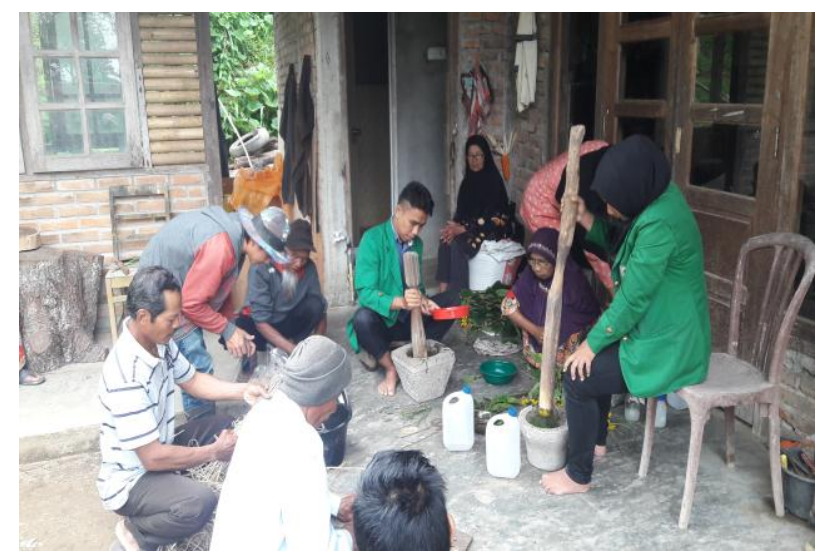

Gambar 5. Anggota Kelompok Tani Sedang Praktek Pembuatan Pestisida Nabati 


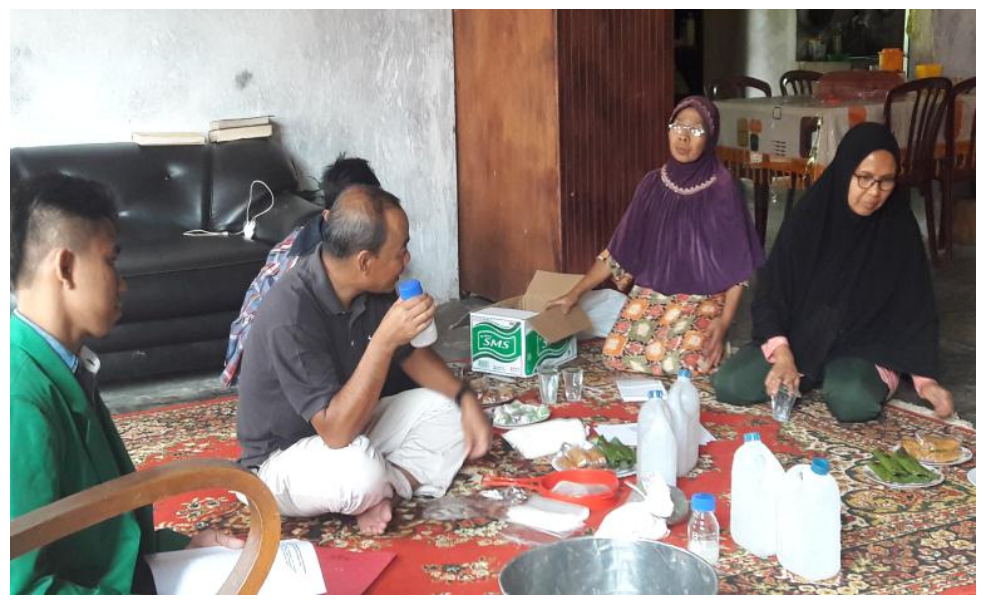

Gambar 6. Anggota Kelompok Tani Sedang Praktek Pembuatan Biopestisida

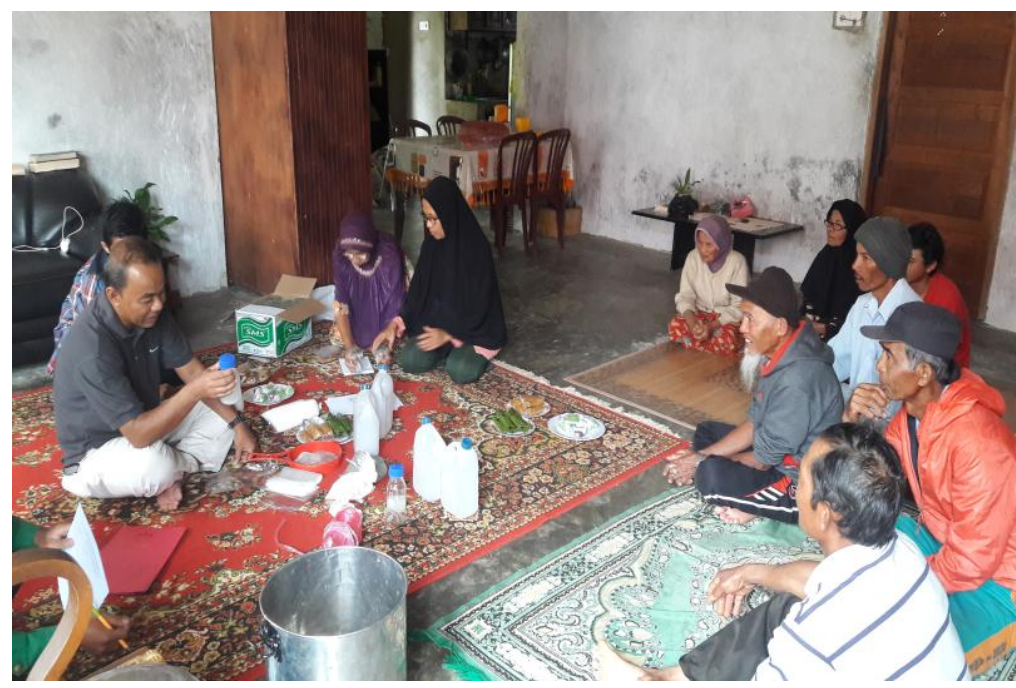

Gambar 7. Anggota Kelompok tani sedang praktek pembuatan biopestisida

Dari kegiatan yang dilakukan terlihat anggota kelompok tani sangat antusias untuk mengikuti kegiatan ini, hal ini terlihat dari aktifitas mereka dalam melakukan diskusi dan tingkat kehadiran yang mencapai $100 \%$. Sebahagian besar anggota mitra belum mengetahui pengendalian OPT dengan memanfaatkan bahan-bahan alam yang ada disekitar mereka, anggota mitra selalu menggunakan pestisida sintetil untuk mengedalikan OPT yang ada pada sayuran mereka. Penggunaan pestisida sintetis yang tidak bijaksana (sangat intensif) akan menimbulkan beberapa dampak yang membahayakan diantaranya: menimbulkan ketahanan pada hama dan penyebab penyakit /patogen (resistensi), mahal, mencemari lingkungan, membunuh mahkluk lain yang bermanfaat

Sesuai dengan program pertanian berkelanjutan yang diterapkan di Indonesia maka teknik pengendalian Organisme Pengganggu Tumbuhan (OPT) harus mengacu pada Pengendalian Hama dan Penyakit secara Terpadu (PHT). Salah satu komponen utama 
dari program PHT adalah pengendalian hayati, yaitu menggunakan mikroorganisme untuk mengendalikan hama dan patogen penyebab penyakit. Keuntungan penggunaan agensia hayati antara lain: ramah lingkungan, berkesinambungan, kesesuaian ekologis, dan dapat diintegrasikan dalam program PHT serta dapat diperbanyak dengan teknologi yang sederhana dan mudah cara aplikasinya.

\section{KESIMPULAN DAN SARAN}

Dari kegiatan yang telah dilakukan dapat diambil beberapa kesimpulan: 1. Tingkat serangan OPT pada tanaman sayuran di lahan mitra daerah ini cukup tinggi, 2. Sebahagian besar anggota mitra belum memahami OPT yang menyerang tanaman sayuran mereka, 3. Sebahagian besar anggota mitra belum memahami metode pengendalian penyakit pada tanaman sayuran, terutama pengendalian dengan menggunakan biopestisida, pestisida botani dan 4. Adanya praktek telah meningkatkan pengetahuan petani tentang pengelolaan OPT sayuran menggunakan biopestisida dan pestisida botani

Dari hasil yang didapat dalam pelaksanaan kegiatan, disarankan agar penyuluhan dan pelatihan semacam ini dapat terus berlanjut atau dilakukan dalam waktu yang agak panjang sehingga petani sayuran dapat mengurangi pestisida sintetik yang selama ini selalu digunakan dalam pengendalian OPT.

\section{DAFTAR PUSTAKA}

Arneti. 2004. Penerapan Penggunaan Pestisida Botani Untuk Pengendalian Hama Spodoptera Exigua Pada Tanaman Bawang Merah di Nagari Canduang Kecamatan Banuhampu Canduang, Sumatera Barat. Dana Proyek Peningkatan Universitas Andalas. Padang Tahun 2004.

Bappeda Kabupaten Agam. 2015. Laporan Kegiatan Dinas Pemerintah Daerah Kabupaten Agam tahun 2014. Badan Perencanaan dan Pembangunan Daerah Kabupaten Agam, Agam.

Dinas Pertanian Tanaman Pangan Hortikultura dan Peternakan Kabupaten Agam. 2014. Laporan serangan OPT di Kabupaten Agam. Laporan Tahunan Dinas Pertanian Tanaman Pangan Hortikultura dan Peternakan Kabupaten Agam, Agam.

Habazar., T, Rivai. F, dan E.F. Husein. 2001. Pemanfaatan Pseudomonas flourescens sebagai agens penginduksi ketahanan tanaman. Jurnal Manggaro. 7(2): 5-12.

Khairul. U, dan Winarto. 2005. Analisis Keragaman Molekuler Bacillus subtilis dengan Teknik RAPD (Random Amplified Polymorphic DNA) dan Studi Potensi Antagonisnya Terhadap Ralstonia solanacearum Penyebab OPT Layu Pada Tanaman Cabai. Laporan Penelitian Dasar. Lembaga Penelitian Unand, Padang. 
Khairul. U dan Reflin. 2008. Kajian Fisiologis dan Molekular Streptomyces sp serta Potensi Biokontrolnya Terhadap Ralstonia solanacearum Penyebab OPT Layu Pada Tanaman Pisang. Laporan Penelitian Dirjen DIKTI, Jakarta.

Khairul U dan Reflin. 2012. Formulasi Biopestisida Indigenus Untuk Pengendalian Penyakit Layu Stewart: Penyakit Baru Pada Tanaman Jagung di Indonesia dan Pengelolaanya. Laporan Penelitian Hibah bersaing. LPPM Unand, Padang.

Semangun. H. 2000. OPT-OPT Tanaman Hortikultura di Indonesia. Gajah Mada University Press, Yokyakarta.

Setiadi. T. 2002. Bercocok Tanam Sayuran. Penebar Swadaya, Jakarta. 